\title{
INFLUENCE OF DRIFTING ON AMINO ACID PROFILES, MINERALS, PHENOLIC CONTENTS AND ANTIOXIDANT ACTIVITY OF THREE MARINE BROWN ALGAE
}

\begin{abstract}
Alaa Ahmed Fathy
Department of Botany, Faculty of Science, Muharram Beck, Alexandria

University, Alexandria, Egypt.

Abstract

Effect of drifting on amino acids profile and mineral content in attached and drift marine algae: Dictyota dichotoma, Sargassum vulgare and Cystoseira spinosa (phaeophyta) was investigated as well as, their antioxidant activity in relation to their total phenolic content. All algae tested displayed similar amino acid patterns, with predominance of aspartic and glutamic acids in their tissues. Total phenolic contents varied from a minimum of $0.22 \mathrm{mg} \mathrm{g}^{-1} \mathrm{dw}$ in drift Cystoseira samples, to a maximum of $0.93 \mathrm{mg} \mathrm{g}^{-1} \mathrm{dw}$ in attached Dictyota samples. The results revealed that drifting negatively affect the phenol content of studied species. The extract of attached and drift $D$. dichotoma found to have the most potent antioxidant activity (45.38 and $33.61 \%$ ), respectively. $\mathrm{Cu}$ and $\mathrm{Na}$ were presented in low values, especially in Dictyota dichotoma, while $\mathrm{Fe}$ and $\mathrm{K}$ were the most abundant elements in all algae analyzed. All micro and macro elements values were negatively affected by drifting, except those values of $\mathrm{K}, \mathrm{Ca}$ and $\mathrm{Mg}$ in Cystoseira samples.
\end{abstract}

Keywords: Drifting, algae, antioxidant activity, phenolic content, minerals.

\section{Introduction}

Seaweeds have been used as food, fertilizers and for medicinal purposes for a long time. Over the last several decades, seaweeds or their extracts have been studied as novel sources which have been shown to produce a variety of inorganic and organic substances, which probably have been reported to possess biological activity of potential medicinal value (Hou \& Yan, 1998; JiménezEscrig \& Goni, 1999; Fallarero et al., 2006; Satoru et al., 2003). Free radicals are responsible for aging and causing various human diseases. Several studies showed that antioxidant substances which scavenge free radicals have been obtained from marine seaweeds (Burtin, 2003; Lim et al., 2002; Zhao et al., 2004). The antioxidants mainly identified as phenolic compounds (Kuda et al., 2005a; Lim et al., 2002). The high phenolic, amino acid and mineral contents in seaweeds, especially brown algae, make them nutritionally and pharmaceutically valuable 
(Jiménez-Escrig and Sanchez-Muniz, 2000; Portugal et al., 1983; Zahra et al., 2007).

Drying may affect the types and proportions of the chemical constituents of algae. As seaweeds can deteriorate rapidly, it is important to transport them to laboratory soon after harvest; so they can be stored for a long time without significant loss of their chemical constituents (Naylor, 1976; Wong \& Cheung 2001a). In general, slow drying under high temperature and exposure circumstances (drifting) may cause chemical and physical degradation in seaweed tissues (Fellows, 1988; Zubia et al., 2003). Drifting could be an important factor affecting the nutritional value of seaweeds either through chemical modifications or direct losses of the nutrients. However, information concerning the effect of drifting on the chemical composition of different seaweeds is limited (Wong \& Cheung 2001a; Zubia et al., 2003).

Among marine algae spread along seashore of Alexandria, brown algae constitute one of the most abundant groups of economic interest. The present work was undertaken to investigate the effect of drifting on some chemical nutritional constituents of three common brown seaweeds: Dictyota dichotoma, Sargassum vulgare and Cystoseira spinosa, in relation to their antioxidant activity.

\section{Materials and Methods}

\section{Study site:}

Abu-Qir Bay is a semi-enclosed basin located about $36 \mathrm{~km}$ east of Alexandria. It lies between $30^{\circ} 05^{\prime}-30^{\circ} 22^{\prime} \mathrm{E}$ and $31^{\circ} 16^{\prime}-31^{\circ} 21^{\prime} \mathrm{N}$. This western inshore area of the bay is a shallow region (with average depth of $3.8 \mathrm{~m}$ ), interrupted with several rocky islets.

\section{Sampling:}

Attached samples of three brown marine algae Dictyota dichotoma, Sargassum vulgare, Cystoseira spinosa were randomly collected and then were brought to the laboratory in dark plastic bags just after harvest. In addition, several samples of drift algal species were cautiously collected and transported to laboratory in dark plastic bags. Then all collected samples were identified, washed with distilled water to remove epiphytes and impurities and then weighed. The algal samples were dried at $60{ }^{\circ} \mathrm{C}$ till constant weight. The dried samples were weighted and ground into a fine powder. All chemical analyses were conducted in triplicate on dried ground material. All values were reported relative to the dry weight of the seaweed. Mean values and standard error were calculated. 


\section{Determination of total amino acids:}

Seven $\mathrm{ml}$ of $\mathrm{HCl}$ with mercapto-ethanol $(5 \mu \mathrm{L} / 10 \mathrm{ml}$ acid) were added to $0.04 \mathrm{mg}$ sample in test tube. The test tubes containing acidified samples were suspended in a vacuum assembly with purified nitrogen purge and evacuated and purged with $\mathrm{N}$ three times, then sealed off. The samples then hydrolyzed at $110^{\circ} \mathrm{C}$ for $22 \mathrm{hrs}$. The test tubes were cooled to room temperature and scibed with a tube cutter, filtered and transferred to $10 \mathrm{ml}$ volumetric flask using deionized water. One $\mathrm{ml}$ of filtrate was dried in a vacuum desiccators in the presence of $\mathrm{NaOH}$. Then the dried sample residues were dissolved in $2 \mathrm{ml}$ diluting sodium citrate buffer ( $\mathrm{pH}$ 2.2) and filtered through filter paper according to the method described by Moore and Stein (1958).

\section{Determination of total phenolic compounds:}

Total phenolic compounds in the fresh and drift brown algae were analyzed in triplicates according to the standard Folin-Ciocalteu method (Velioglu et al., 1998). One $\mathrm{ml}$ aliquot of each algal sample placed in a test tube contained $1.5 \mathrm{ml}$ de-ionized water as well as $0.5 \mathrm{ml}$ of $0.1 \mathrm{M}$ Folin-Ciocalteu reagent was added. After $1 \mathrm{~min}, 1.0 \mathrm{ml} 20 \% \mathrm{Na}_{2} \mathrm{Co}_{3}$ was added to the mixture followed by vortexmixing. The reaction mixture was allowed to stand for $60 \mathrm{~min}$ in darkness. The control contained all the reaction reagents except the algal sample. The total phenolic compounds were determined colorimetrically at $750 \mathrm{~nm}$ using a spectrophotometer, and compared to a gallic acid calibration curve.

\section{Antioxidant activity for DPPH (1, 1-diphenyl-2-picrylhydrazyl) free radical scavenging activity:}

Scavenging activity of algal samples towards DPPH free radical was performed according the method of Yen and Chen (1995). Two ml aliquot of tested algal samples (in methanol: chloroform, 2:1) were added to $2.0 \mathrm{ml}$ of 0.16 $\mathrm{mM}$ DPPH methanolic solution. The mixture was vortexed for $1 \mathrm{~min}$ and then left to stand at room temperature for $30 \mathrm{~min}$ in the dark, then the absorbance was read at $517 \mathrm{~nm}$. The capability to scavenging the DPPH radical was calculated using the following equation according to (Zhang et al., 2006):

Scavenging effect $(\%)=\left\{1-\left(\mathbf{A}_{\text {sample }}-\mathbf{A}_{\text {sample blank }}\right) / \mathbf{A}_{\text {control }}\right\} \times 100$

Where $\mathrm{A}_{\text {control }}$ is the absorbance of control (DPPH without algal samples), $\mathrm{A}_{\text {sample }}$ is the absorbance of algal sample with DPPH, and A sample blank is only the absorbance of algal sample (without DPPH).

\section{Determination of reducing power:}

The reducing power of algal samples was determined as described by Dorman et al., (2003). One ml of each sample was mixed with $1.0 \mathrm{ml}$ of $0.2 \mathrm{M}$ phosphate buffer ( $\mathrm{pH} 6.6$ ) and $2.5 \mathrm{ml}$ of $1 \%$ aqueous potassium hexacyanoferrate solution. The reaction mixture was left for $30 \mathrm{~min}$ at $50^{\circ} \mathrm{C}$, then $1.5 \mathrm{ml}$ of $10 \%$ 
trichloroacetic acid were added. The mixture was then centrifuged at $2500 \mathrm{rpm}$ for $10 \mathrm{~min}$. Finally distilled water and $0.5 \mathrm{ml}$ of $0.1 \%$ aqueous $\mathrm{FeCl}_{3}$ were added, and the absorbance was measured at $700 \mathrm{~nm}$. The data were presented as ascorbic acid equivalent (AscAE) in milligrams of ascorbic acid per gram of extract.

\section{Determination of elements:}

Part of each algal samples were oven dried at $65^{\circ} \mathrm{C}$ till constant weight obtained. Three grams of each dry sample were dried in muffle at $550^{\circ} \mathrm{C}$ for an hour, digested using concentrated $\mathrm{HCl}$ and $\mathrm{HNO}_{3}$, then completed to a definite volume and analyzed for their metal content according to the method of Martin (1979) using Atomic Absorption or emission spectrophotometer.

\section{Results}

The effect of drifting on amino acid profiles are presented in Table 1. The amounts of amino acids of all drift samples were significantly $(\mathrm{p}<0.05)$ lower than those of the attached algal samples. Moreover, due to drifting, the damage of the amino acids seemed to be non-specific, since the differences on the level of individual amino acids between the attached and the drift algal samples showed no particular trend (Table 1). The tested algae displayed similar amino acid patterns, with a predominance of aspartic and glutamic acids in their tissues.

Total phenolic contents of the three tested algae were presented in Figure 1A. It varied from a minimum of $0.22 \mathrm{mg} \mathrm{g}^{-1} \mathrm{dw}$ in drift Cystoseira samples, to a maximum of $0.93 \mathrm{mg} \mathrm{g}^{-1} \mathrm{dw}$ in attached Dictyota samples. Attached and drift samples of $D$. dichotoma exhibited the maximum phenolic content among the other algal samples analyzed. From Figure 1A, it was obvious that drifting negatively affect the phenol content of studied algal species. Dictyota dichotoma was the least species affected by drifting, where it lost only $16.13 \%$ of its phenolic content, while Sargassum and Cystoseira lost about 23.89 and $51.11 \%$, respectively of their phenolic content.

All algal samples possessed the antioxidant ability to various degrees (Figure 1B). Of the tested algae, the extract of Dictyota (attached and drift samples) found to have the most potent antioxidant ability (45.38 and 33.61\%). Extract of Sargassum and Cystoseira showed nearly equal scavenging values towards DPPH for attached $(17.5 \& 17.0 \%)$ and drift samples (10.97\& $10.03 \%)$, respectively (Figure 1B). In general, the higher total phenolic content of algal samples resulted in higher antioxidant capacity. Reducing power of the tested algae was represented in Figure 1C. On the basis of ascorbic acid equivalent (AscAE) values, extract of attached Dictyota samples showed the maximum $\left(2.64 \mathrm{mg} \mathrm{g}^{-1}\right)$ reducing power rather than other studied algal extract. From Figure 1C, it

Egyptian J. of Phycol. Vol. 9, $2008 \quad$ - 74 - 
Table 1. Influence of drifting on amino acid profiles $\left(\mathrm{mg} \mathrm{g}^{-1} \mathrm{dw}\right)$ of the brown algae Dictyota dichotoma, Sargassum vulgare and Cystoseira spinosa from Alexandria.

\begin{tabular}{c|cc|cc|cc}
\hline $\begin{array}{c}\text { Amino Acids } \\
\text { (mg g-1 dw) }\end{array}$ & \multicolumn{2}{|c|}{$\begin{array}{c}\text { Dictyota } \\
\text { dichotoma }\end{array}$} & \multicolumn{2}{c|}{$\begin{array}{c}\text { Sargassum } \\
\text { vulgare }\end{array}$} & \multicolumn{2}{c}{$\begin{array}{c}\text { Cystoseira } \\
\text { spinosa }\end{array}$} \\
\cline { 2 - 7 } & Attached & Drifted & Attached & Drifted & Attached & Drifted \\
\hline Aspartic acid & 7.70 & 5.70 & 6.88 & 4.90 & 5.33 & 3.98 \\
Therionine & $\mathbf{1 . 3 7}$ & $\mathbf{1 . 3 0}$ & 3.11 & 2.70 & 2.00 & 1.72 \\
Serine & $\mathbf{1 . 2 0}$ & $\mathbf{1 . 2 1}$ & 1.79 & 1.60 & 1.55 & 1.44 \\
Glutamic acid & 8.00 & 5.00 & 8.03 & 7.07 & 6.31 & 6.01 \\
Proline & 1.27 & 0.98 & $\mathbf{2 . 7 2}$ & $\mathbf{2 . 7 0}$ & $\mathbf{1 . 9 2}$ & $\mathbf{2 . 0 0}$ \\
Glycine & 3.02 & 2.64 & $\mathbf{4 . 1 0}$ & $\mathbf{3 . 9 1}$ & 2.74 & 2.56 \\
Alanine & 3.91 & 2.70 & 4.01 & 3.93 & 2.00 & 2.01 \\
Valine & 2.78 & 2.10 & $\mathbf{3 . 0 0}$ & $\mathbf{2 . 9 5}$ & $\mathbf{2 . 0 0}$ & $\mathbf{1 . 8 2}$ \\
Methionine & 0.62 & 0.43 & 0.71 & 0.56 & 0.73 & 0.81 \\
Isoleucine & 2.07 & 2.14 & 2.76 & 2.51 & 1.54 & 1.86 \\
Leucine & 3.89 & 3.51 & 4.21 & 4.00 & 3.02 & 2.64 \\
Tyrosine & 0.76 & 0.53 & $\mathbf{0 . 7 0}$ & $\mathbf{0 . 5 1}$ & 0.87 & 0.77 \\
Phenylalanine & 1.93 & 1.60 & 2.00 & 1.61 & 1.84 & 2.11 \\
Histidine & 2.31 & 2.20 & 2.42 & 1.90 & $\mathbf{1 . 9 0}$ & $\mathbf{1 . 9 0}$ \\
Lysine & 0.61 & 0.55 & 0.69 & 0.57 & 0.76 & 0.53 \\
Arginine & 2.86 & 2.24 & 3.00 & 2.53 & $\mathbf{1 . 7 5}$ & $\mathbf{1 . 6 0}$ \\
\hline
\end{tabular}

Bold numbers means that the difference between attached and drifted amino acid values are not significant $(p<0.05)$. Tryptophan and cystine are not detected. 
Alaa Ahmed Fathy
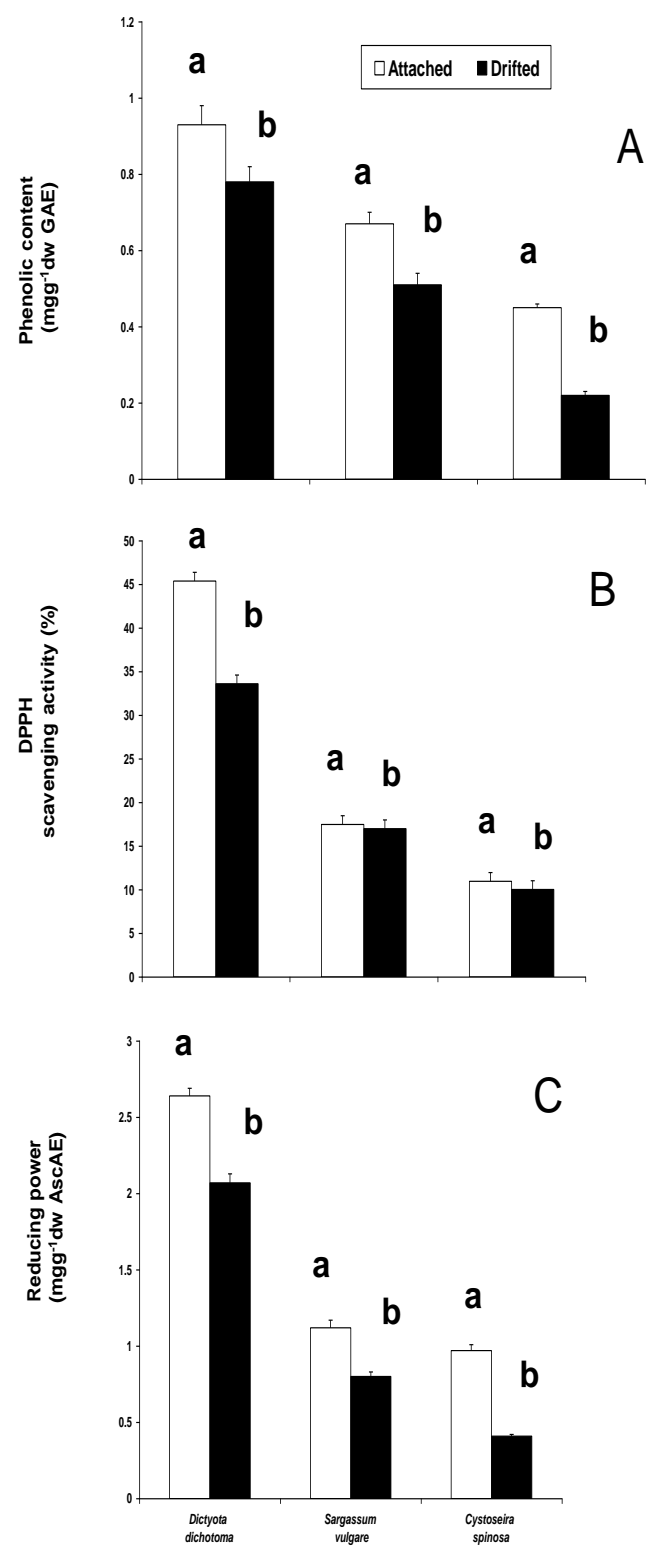

Figure 1. Effect of drifting on total phenolic content $\left(\mathrm{mg} \mathrm{g}^{-1} \mathrm{dw}\right)(A)$, DPPH Scavenging activity (\%) (B), and reducing power (\%) (C) of three brown algae. Different letters on Columns for each species means significant at $p<0.05$. 
appeared clearly that, drifting significantly decrease the reducing power ability of all analyzed algal samples.

Figure $2 \& 3$ represent the macro and micro elements concentrations measured in attached and drift algal samples. $\mathrm{Cu}$ and $\mathrm{Na}$ were present in low concentrations in all species tested, especially in Dictyota dichotoma. Fe and $\mathrm{K}$ were the most abundant elements, where the maximum Fe concentration $\left(1801 \mu \mathrm{g} \mathrm{g}^{-1} \mathrm{dw}\right)$ was measured in drift sample of Sargassum, while the maximum K value $(10.2 \% \mathrm{dw})$ was recorded for drift Cystoseira samples. High concentrations of macro elements were observed in attached and drift tissues of Cystoseira spinosa, while high values of micro elements were measured in attached and drift samples of Sargassum vulgare. Mineral contents of tested algae varied in all attached and drift algal samples analyzed, without particular trend. In general, all micro and macro elements values were negatively affected by drifting, except those values of $\mathrm{K}, \mathrm{Ca}$ and $\mathrm{Mg}$ in Cystoseira samples.

\section{Discussion}

The non-specific degradation of amino acids by drifting on the studied brown algae agrees with the findings of Chan et al. (1997). In the present work, the analyzed species contained all the essential amino acids (except tryptophan) in different proportions. Similar results were obtained from other brown algae by other workers (Qasim, 1991; Behairy \& El-Sayed, 1983). The dominance of aspartic and glutamic acids in all tested algae were in agreement with the findings reported by several researchers (Fleurence, 1999; Wong \& Cheung 2001a). In our study, the concentrations of Methionine, Tyrosine and Lysine were low, which is agreement with the work of Portugal et al., (1983) on several brown seaweeds. The brown algae in general appear to be deficient in sulphur-containing amino acids (Fleurence, 1999; Zubia et al., 2003). Furthermore, the individual amino acid values recorded for the three tested species were comparable to the values recorded for other brown algae by several workers (Zubia et al., 2003; Wong \& Cheung, 2001a).

Phenolic compounds have been highly regarded for their important dietary roles as antioxidative and chemopreventive agents (Bravo, 1998; Ismail \& Hong, 2002; Kuda et al., 2005a). The results obtained indicated that the three analyzed algal species possess considerable phenolic content in their tissues. These findings appear useful in leading to the development of therapeutic products from Egyptian marine algae. Different methods for determination of antioxidant activity have been developed and used to screen various plant samples (Zhang et al., 2006). In our study, the DPPH radical scavenging assay method was successfully used to assess the total antioxidant capacity of the marine algal extracts, being simple, fast, and reliable. The extract of Dictyota showed the 


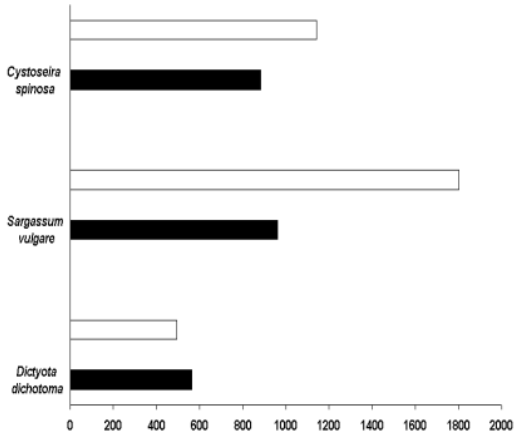

Mn

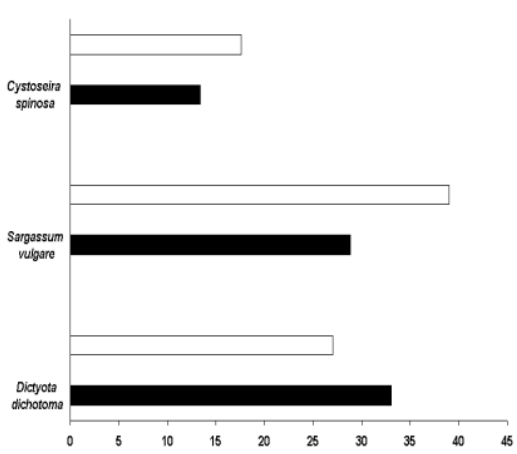

$\mathrm{Cu}$

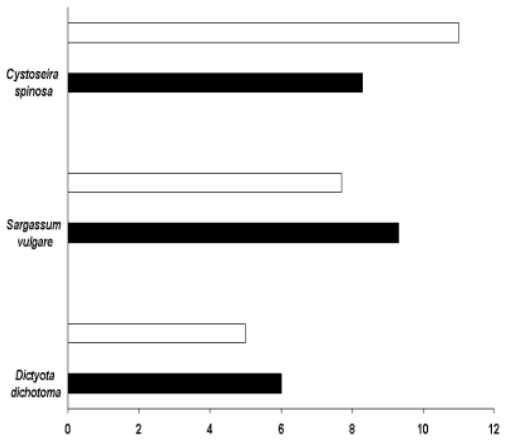

$\mathrm{Zn}$

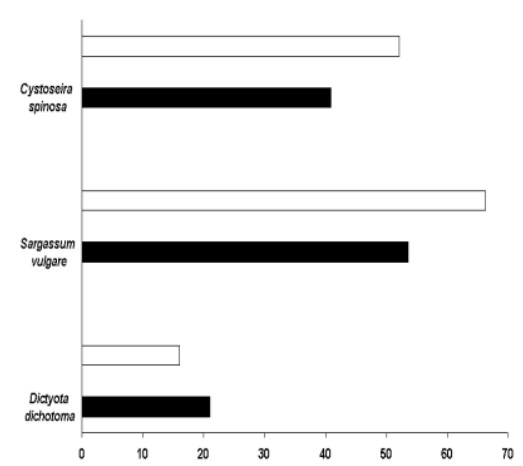

Element concentrations $\left(\mu \mathrm{gg}^{-1} \mathrm{dw}\right)$

Figure 2. Microelement concentrations in attached (white columns) and drift (black columns) brown algae. 
$\mathrm{Zn}$

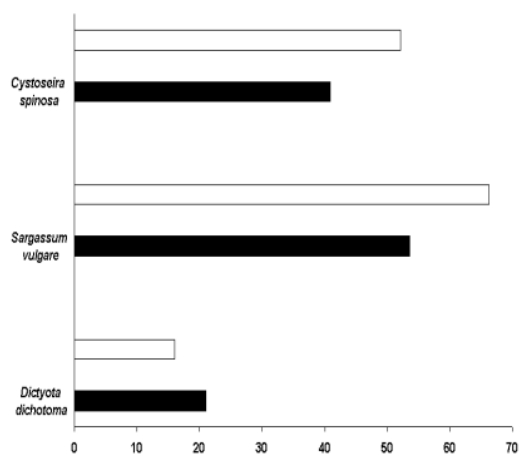

Na

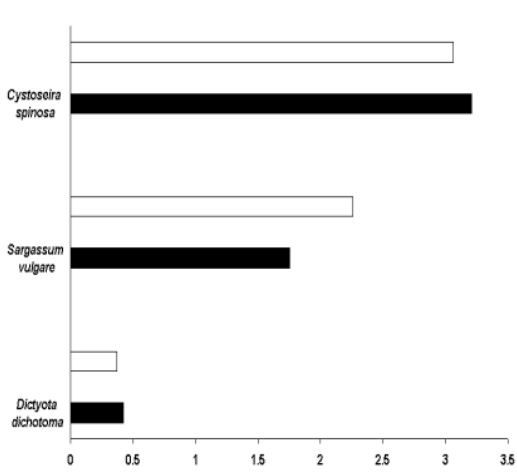

Ca

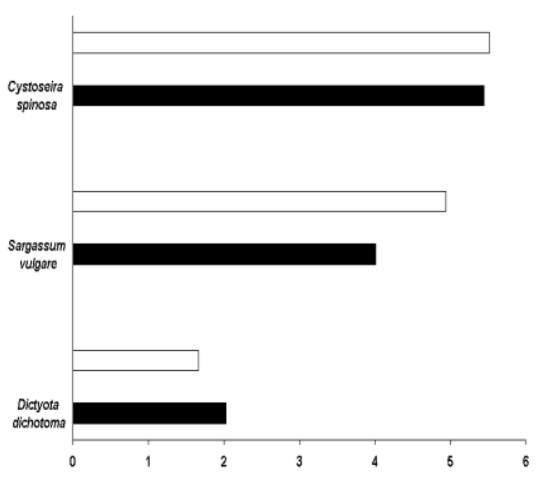

$\mathrm{Mg}$

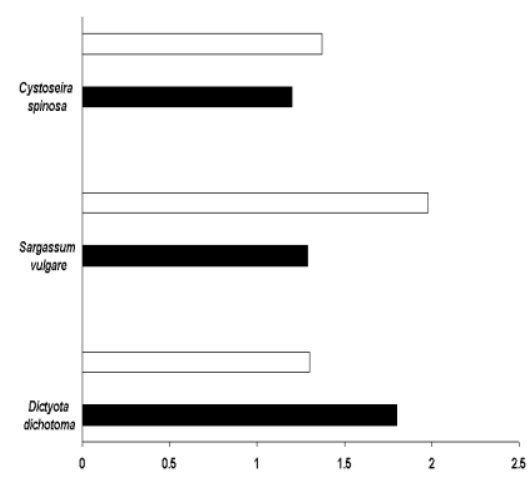

Element concentrations ( $\% \mathrm{dw}$ )

Figure 3. Macroelement Concentrations (\% dw) in attached (white columns) and drift (black columns) brown algae. 
highest antioxidant activity, as well as, the highest content of phenolic components. However, the previous results were not confirmed statistically, where there was not significant association between the total phenolic content and DPPH radical scavenging activity. Previous reports mentioned that there was a direct relationship between the antioxidant activity and the total phenolic content in plants (Velioglu et al., 1998). However, there were also some reports, which indicated no such positive relationship (Kähkönen et al., 1999). A possible explanation for these disparate different results is that, the total phenolic content did not include all the antioxidants. However, it could be suggested that some other antioxidants, which are structurally different from phenolics are present in the tested materials (Sun and Ho, 2005; Zhang et al., 2006). In the present study the statistical analysis proved that drifting negatively affect the total phenolic compounds in all tested algae, which argue with the findings reported by Chan et al., (1997) working on other algae, and was in agreements with the findings of Jiménez-Escrig et al., (2001), who suggested that drifting and exposure circumstances could decrease the antioxidant activity. Furthermore, the phenolic content, antioxidant activity and reducing power of the three tested algae were comparable to values reported for other seaweeds species (Zhang et al., 2006; Shanab, 2007; Ismail \& Hong, 2002; Zahra et al., 2007).

Concentrations of $\mathrm{Fe}, \mathrm{Mn}, \mathrm{Zn}, \mathrm{K}$ and $\mathrm{Ca}$ were high in all analyzed algal samples, which is consistent with the results obtained by other reporters (Chan et al., 1997; Hou \& Yan, 1998; McDermid \& Stuercke, 2003). Such observations could suggest the use of the algae under investigation as natural agricultural fertilizers due to their richness in mineral content. Drifting significantly causes most of the investigated minerals to be accumulated in the tissue of analyzed algal species. This may suggest using attached, as well as, drift marine seaweeds as natural mineral source in agricultural fertilizers, also may be cautiously used in pharmaceutical industries due to their high mineral content.

\section{Conclusion}

1. The three analyzed brown algae contain considerable amounts of amino acids in their attached as well as in drifted samples, which may favored their using in some nutritional and pharmaceutical natural products.

2. Due to their richness in elements, they may used as fertilizers, but caution must be taken when using them as food supplements, especially for hypertensive persons.

3. All analyzed algae possessed considerable antioxidant activity, which favors using them in pharmaceutical industry as natural anti-aging. 
4. In general, a complete screening is needed to screen algal flora along northern (Mediterranean Sea) and eastern (Red Sea) coasts of Egypt, which aimed at detailed investigation and characterization of their phenolic content in relation to their antioxidant activity.

\section{References}

Behairy, A. K. A. and M. M. El-Sayed , (1983). Biochemical composition of some marine brown algae from Jeddah coast, Saudi Arabia. Indian J. Mar. Sci. 12:200-201.

Bravo, L., (1998). Polyphenols: Chemistry, dietary source, metabolism, and nutritional significance. Nutr. Rev. 56:317-333.

Burtin, P., (2003). Nutritional value of seaweeds. Elect. J. Environ. Agric. Food Chem. 2(4):498-503.

Chan, C.C.J., P.C.K. Cheung and PO. Jr. Ang, (1997). Comparative studies on the effect of three drying methods on the nutritional composition of seaweed Sargassum hemiphyllum (Turn.) C. Ag. J. Agric. Food Chem. 45:3056-3059.

Dorman, H. J. D., M. Kosar, K. Kahlos, Y. Holm and R. Hiltunen , (2003). Antioxidant properties and composition of aqueous extracts from Mentha species, Hybrids, varieties, and cultivars. J. Agric. Food Chem. 51:45634569.

Fallarero, A., A. Peltoketo, J. Loikkanen, P. Tammela, A. Vidal and P. Vuorela, (2006). Effects of the aqueous extract of Bryothamnion triquetrum on chemical hypoxia and aglycemia-induced damage in GT 1-7 mouse hypothalamic immortalized cells. Phytomed.13:240-245.

Fellows, P., (1988). Food processing technology principal and practice. Ellis Horwood Ltd., London, pp. 304-313.

Fleurence, J., (1999). Seaweed proteins: Biochemical, nutritional aspects and potential uses. Trends Food Sci. Technol. 10:25-28.

Hou, X. and X. Yan, (1998). Study on the concentration and seasonal variation of inorganic elements in 35 species of marine algae. Sci. Total Environ. 222:141-156.

Ismail, A. and T. S. Hong, (2002). Antioxidant activity of selected commercial seaweeds. Mal. J. Nutr. 8(2):167-177.

Jiménez-Escrig, A. and C. I. Goni, (1999). Nutritional evaluation and physiological effects of edible seaweeds. Arch. Latinoam Nutr. 49:114-120.

Jiménez-Escrig, A. and F. Sanchez-Muniz, (2000). Dietary fiber from edible seaweeds: Chemical structure, physiochemical properties effects on cholesterol metabolism. Nutr. Res. 20(4):585-598.

Egyptian J. of Phycol. Vol. 9, $2008 \quad$ - 81 - 
Jiménez-Escrig, A., I. Jiménez-Jiménez, R. Pulido and F. Saura-Calixto, (2001). Antioxidant activity of fresh and processed edible seaweeds. J. Sci. Food Agric. 81:530-534.

Kähkönen, M. P., A. I. Hopia, H. J. Vuorela, J. P. Rauha, K. Pihlaja, T. S. Kujala and M. Heinonen, (1999). Antioxidant activity of plant extracts containing phenolic compounds. J. Agric. Food Chem. 47:3954-3962.

Kuda, T., M. Tsunekawa, H. Goto andY. Araki, (2005a). Antioxidant properties of four edible algae harvested in the Noto Peninsula, Japan. J. Food Compos. Anal. 18:625-633.

Lim, S. N., P. C. K. Cheung, V. E. C. Ooi and P. O. Ang, (2002). Evaluation of antioxidative activity of extracts from brown seaweed, Sargassum siliquastrum. J. Agric. Food Chem. 50:3862-3866.

Martin, J. H., (1979). Bioaccumulation of heavy metals by littoral and pelagic marine organisms. ESA 600:377-380.

McDermid, K. J. and B. Stuercke, (2003). Nutritional composition of edible Hawaiian seaweeds. J. App. Phycol. 15:513-524.

Moore S. and Stein H. W. (1958). Chromatography of amino acids on sulfonated polysytyrene resins. Anal. Chem. 30:1185-1193.

Naylor, J., (1976). Production, Trends and Utilization of seaweeds and seaweeds products. In FAO fishers technical paper No. 159. Food and agricultural organization of United Nations, Rome, Italy, pp.1-71.

Portugal, T. R., E. O. Ladines, S. S. Ardena, L. Resurreccion, C. R. Medina and P. M. Matibag, (1983). Nutritive value of some Philippine seaweeds. Part II. Proximate, amino acid and vitamin composition. Philipp. J. Nutr. 166-172.

Qasim, R., (1991). Amino acids composition of some seaweed. Pakistan $J$. Pharm. Sci. 4:49-54.

Satoru, K.; T. Naboru, N. Hiroo, S. Shinji and S. Hiroshi, (2003). Oversulfation of fucoidan enhances its anti-angiogenic and anti-tumor activities. Biochem. Pharm. 65:173-179.

Shanab, S. M. M., (2007). Antioxidant and antibiotic activities of some seaweeds (Egyptian Isolates). Inter. J. Agric. Biol. 9(2):220-225.

Sun, T. and C. T. Ho, (2005). Antioxidant activities of buckwheat extract. Food Chem. 90:743-749.

Velioglu, Y. S., G. Mazza, Gao L. and B. D. Oomah , (1998). Antioxidant activity and total phenolics in selected fruits, vegetables, and grain products. J. Agric. Food Chem. 46:4113-4117.

Wong, K. and P. C. Cheung , (2001a). Influence of drying treatment on three Sargassum species. 1. Proximate composition, amino acid profile and some physio-chemical properties. J. Appl. Phycol. 13:43-50.

Yen, G.C. and H. Y. Chen, (1995). Antioxidant activity of various tea extracts in relation to their antimutagenicity. J. Agric. Food Chem. 43:27-37.

Egyptian J. of Phycol. Vol. 9, $2008 \quad$ - 82 - 
Zahra, R.; M. Mehranian, F. Vahabzadeh and K. Sartavi , (2007). Antioxidant activity of brown algae Sargassum vulgar and Sargassum angustrifolium. J. Aquat. Food Prod. Technol. 16(2):17-26.

Zhang, W., X. J. Duan, H. L. Huang, Y. Zhang and B. G. Wang , (2006). Evaluation of 28 marine algae from the Qingdao coast for antioxidative capacity and determination of antioxidant efficiency and total phenolic content of fractions and subfractions derived from Symphycocladia latiuscula (Rhodomelaceae).

Zhao, X., C.H. Xue, Z. J. Li, Y.P. Cai, H.Y. Liu and H.T. Qi, (2004).

Antooxidant and hepatoprotective activities of low molecular weight sulfated polysaccharide from Laminaria japonica J. App. Phycol. 16:111115.

Zubia, M., C.E. Payri, E. Deslandes and J. Guezannec, (2003). Chemical composition of attached and drift specimens of Sargassum mangarevense and Turbinaria ornate (Phaeophyta:Fucales) from Tahiti, French Polynesia Bot. Mar. 46:562-571.
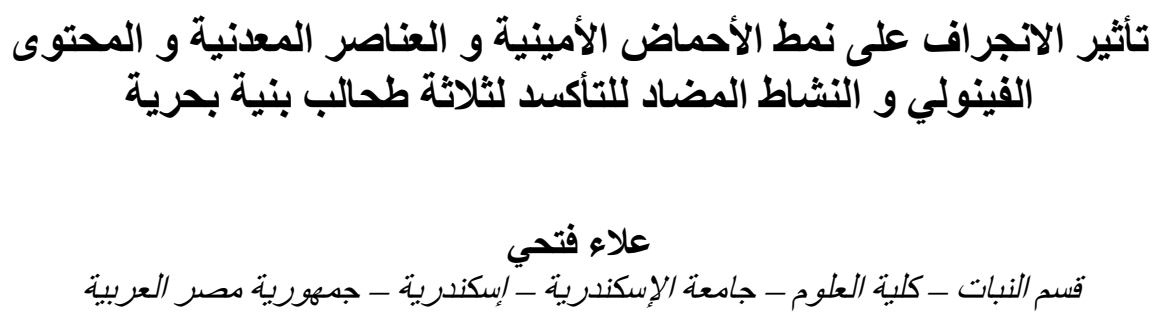

تمت دراسة أثر الانجر اف على نمط الأحماض الأمينيّة و محتوُى المعادن في الطحالب البحريّة

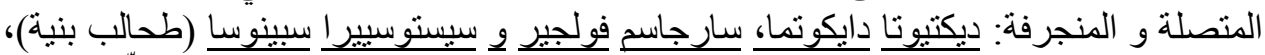

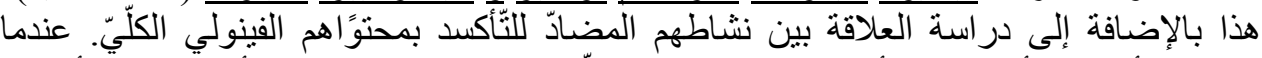

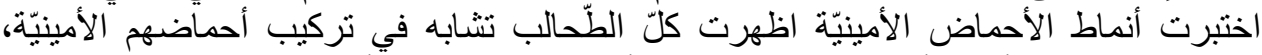

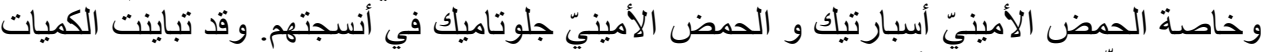

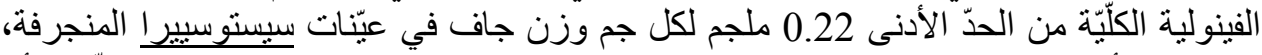

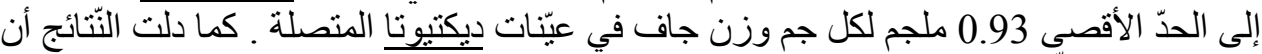

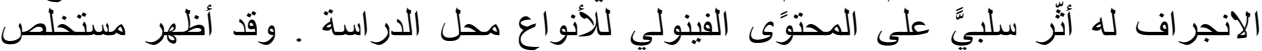
ديكتيوتا دايكوتوما المتصلة و المنجرفة نشاطا مضادا للتنّاكسد الأكثر فاعليّة (45.38 و 33.61

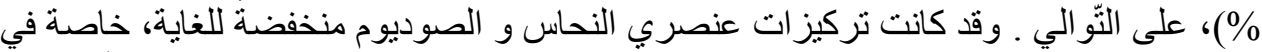

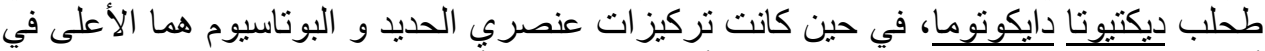

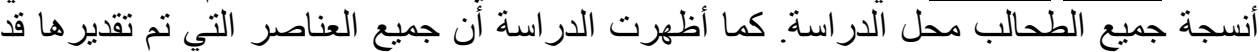
تأثرت سلبيا بعامل الانجر اف فيما عدا عنصري البوتاسيوم و الكالسيوم في عينات طحلب النافي 